\title{
Institutions for European Energy Cooperation: Dyadic Data Analysis of Electricity Network Interconnections
}

\author{
Hyodong Sohn and Taedong Lee
}

\begin{abstract}
Europe is the region that has pursued regional cooperation and integration most enthusiastically. The integration of energy systems is what Europe seeks to have synergistic effects. This study examines European energy cooperation by focusing on the driving factors of electricity network interconnections measured as electricity exchange flows. Considering the socioeconomic conditions and the benefits and costs of electricity system integration, it is puzzling why some countries' electricity systems have been connected and have significant electricity flows, while others do not. Furthermore, this study asks what political, institutional, and economic drivers influence the different levels of electricity exchange flows between European countries. While extant studies have looked at the dynamics of energy cooperation, studies to understand electricity network cooperation and integration have been rare. To fill this gap, this study explains the variation of exchange flows by analyzing the dyadic data of 41 European countries in 2013. The statistical analysis suggests that the degree of current policy coordination of regional transmission system operator networks is positively associated with the level of current exchange flows. However, not all institutions are effective in increasing electricity flows. This finding implies that the experience of energy cooperation through effective institutions, along with geographic proximity and the economic benefits of trade, increases electricity network interconnections.
\end{abstract}

Key Words: energy cooperation, institution, electricity network interconnection, European Union, Transmission System Operator networks

*Hyodong Sohn(appick17@naver.com) received a master's degree in political science from Yonsei University. His research interest is examining the politics and policy dynamics of various political actors in relation to myriad global energy and environmental issues.

***Taedong Lee(tdlee@yonsei.ac.kr) is an associate professor in the Department of Political Science and International Stuides at Yonsei University, Seoul. His areas of research include global and subnational environmental politics and policy, NGO politics, international political economy, and social network analysis. His articles have appeared in journals including Policy Sciences, Policy Studies Journal, Energy Policy, Global Environmental Politics and other Korean and international peer-reviewed publications.

This work was supported by the Brain Korea 21 Plus Program and the National Research Foundation of Korea (NRF 2017-11-0420 and NRF-2016S1A3A2924409). The authors wish to thank discussants at the ISA 58th Annual Convention, Baltimore, and three anonymous reviewers for comments on this article. 
U nder the Energy Union Package published by the European Commission (EC) in 2015 and titled A Framework Strategy for a Resilient Energy Union with a Forward-Looking Climate Change Policy (European Commission 2015b), the EC announced how it would integrate the energy sectors among European Union (EU) member countries. The plan emphasized the need for an energy union and suggested fundamental changes from a centralized, supplier-centric, fossil fuel-based energy system to a secure, sustainable, and affordable energy system. The package presented concrete aims and measures for the electricity market. According to the publication, the EC wanted to pursue and meet a 10-percent electricity interconnection (grid) target for all member states by 2020 and have a complete integration of the regional energy market (European Commission 2015a). As of 2015, 12 member states in the EU, including Portugal (7 percent), the Baltic States (4 percent), and Spain (3 percent), remain as target countries to accomplish the 10-percent goal set by the EC.

In addition to the interconnection of electricity grid installations at the EU level, electricity exchanges and trade have also occurred in Europe. According to the European Network of Transmission System Operators (ENTSO-E), the amount of electricity exchanged in Europe in 2014 (464,280 GWh) increased about 22 percent compared to that in 2010 (381,589 GWh) (ENTSO-E 2015). Despite the increasing volume of electricity exchanges in general, however, the specific amount and dynamics of electricity trade still vary between countries and sub-regions in Europe. For instance, electricity interconnections, represented by electricity trading, were the highest between Germany and the Netherlands at 24,939 GWh and the lowest between Hungary and Russia at 20 GWh.

Given these circumstances, this study poses the following questions. First, which factors influence the different levels of exchange flows between countries, and second, how are the factors of cooperative experiences in regional and supranational institutions, geographic proximity, and electricity market size related to the level of electricity integration? By answering these questions, this study contributes towards identifying and explaining the drivers for energy cooperation in the European context. In particular, this study highlights the roles of regional energy authorities as institutions for energy policy coordination.

The composition of this study is as follows. To answer the aforementioned research questions, the study first looks at, and theorizes about, the concept of energy cooperation. Then, the study elaborates on the role of electricity-related institutions and interconnections through the institutions' electricity networks in Europe as a mode of energy cooperation. Later, the research design and hypotheses are explained. Subsequently, by analyzing the association between the degree of historical policy coordination of the regional Transmission System 
Operators (TSO) networks and current exchange flows using the dyadic data analysis, this study will illuminate the crucial factors that explain Europe's functional cooperation in the area of energy.

\section{THEORIZING ELECTRICITY ENERGY COOPERATION}

Cooperation usually refers to the action of working together for a common purpose or benefit. An examination of cooperation usually touches upon such questions as the conditions under which political actors cooperate. The answers are critical because actors often fail to cooperate even if there are potential mutual benefits. Keohane (2005) examined the conditions when cooperation happened in various areas of international political economy and he conceptualized cooperation as a very political process of mutual policy coordination that takes place in actual and potential discord, not in harmony. He regarded intergovernmental cooperation as taking place "when the policies actually followed by one government are regarded by its partners as facilitating realization of their own objectives, as the result of a process of policy coordination" (Keohane 2005, 51-52).

Regional cooperation, among other forms of cooperation, has been developed through the vast literature dealing with regionalism in studies of international politics, the EU, and other regions. The forms of regional cooperation vary: economic cooperation includes a certain degree of favorable trade conditions, and political cooperation includes mutual support and commitment to the implementation of specific values and practices. There are also forms of cooperation in diplomatic and security relationships. Among the topics of regional cooperation, this study looks at energy cooperation; in particular, cooperation as it relates to electricity integration. Energy cooperation can be defined as the action when the policies actually followed by one political actor are regarded by its partners as facilitating the realization of their own objectives as a result of a process of policy coordination of the energy agenda in the fields of international political economy.

However, as Hughes and Lipscy have pointed out, "much of the early work on international energy cooperation focused on two international organizations," OPEC and the IEA, thus, related works needed to return to a discussion of cooperation in other energy-related markets and their dynamics (Hughes and Lipscy 2013, 456-457). Other than international cooperation through formal agreements on climate change (Bättig and Bernauer 2009; Tingley and Tomz 2014), the issues of oil (Ross and Voeten 2015) and gas (Victor et al. 2006) 
can be other important topics in energy cooperation (Hughes and Lipscy 2013, 462-464). This implies that the actual subject, geographical scope, mode, level of engagement, and consideration of actions vary by agenda. Therefore, based on these respective agendas, looking at the costs and benefits of certain policy coordination processes will help identify the characteristics of specific energy cooperation initiatives.

When the policy coordination process is viewed as an important process of regional cooperation, attempts to grasp the nature of cooperation provide a different perspective when cooperation is viewed in terms of regulatory coordination. While examining energy cooperation with an emphasis on its policy coordination process allows us to identify concrete adjustment benefits and costs, depending on different agendas for cooperation, grasping the formation of policy through regulatory coordination helps us to understand the process of cooperation in satisfying the ultimate policy goal (Wallace 2010).

However, under the studies that deal with various aspects of energy cooperation, those that look at electricity energy cooperation using quantitative methods and political economy perspectives have been rare. Especially within the European region, which is considered as having a high degree of energy cooperation compared to other regions (Lee 2007; Nicolas 2009), studies related to energy cooperation have been either about EU energy policy and its regulatory processes (Buchan 2015) or about geopolitical issues related to Russian gas (Casier 2011). Here, we contribute to this line of research by examining the European electricity network interconnections as a unique area of energy cooperation.

To explain electricity cooperation, we need to consider the attributes of electricity in terms of both its industrial structure and its use as an energy resource. Considering each of these attributes will provide us with classifications according to both the benefits of cooperation and the processes of policy coordination (Cameron 2007; Meisen and Mohammadi 2010). ${ }^{1}$ All three attributes become useful in identifying the particularities of the electricity network interconnections as a mode of energy cooperation.

\footnotetext{
${ }^{1}$ Regardless of the nature and attributes of electricity, liberalization policies of the electricity market are known to decrease electricity prices and strengthen transparency through competition, just like other single-market policies. These effects are considered to be the greatest benefits of electrical energy cooperation (Parisio and Bosco 2008). In addition, the electricity trading between countries can lead to direct economic benefits through mutual trading in times of peak load (Korean Power Exchange 2011). However, in this study, these specific features are not provided in much detail because we seek to determine the peculiar nature of electricity energy cooperation based on a study of the international political economy.
} 
Table 1. Characteristics of Electricity and Electrical Energy Cooperation

\begin{tabular}{|c|c|c|c|c|}
\hline Attributes of Electricity & $\begin{array}{c}\text { Type of } \\
\text { Attributes }\end{array}$ & $\begin{array}{l}\text { Problems of } \\
\text { Cooperation }\end{array}$ & $\begin{array}{l}\text { Benefits of } \\
\text { Cooperation }\end{array}$ & $\begin{array}{l}\text { Process of Policy } \\
\text { Coordination }\end{array}$ \\
\hline $\begin{array}{l}\text { Electricity is exchanged } \\
\text { under the structure of } \\
\text { networks }\end{array}$ & $\begin{array}{l}\text { - Industrial } \\
\text { structure }\end{array}$ & $\begin{array}{l}\text { - Installation of } \\
\text { electricity grid / } \\
\text { infrastructure }\end{array}$ & $\begin{array}{l}\text { - Decreased cost of } \\
\text { electricity exchange } \\
\text { - Decreased cost of } \\
\text { investing in power } \\
\text { plants }\end{array}$ & $\begin{array}{l}\text { - Coordination over } \\
\text { constructing grid } \\
\text { installations }\end{array}$ \\
\hline $\begin{array}{l}\text { Electricity has various } \\
\text { technical characteristics } \\
\text { depending on how it is } \\
\text { generated }\end{array}$ & $\begin{array}{l}\text { • Energy } \\
\text { resource }\end{array}$ & $\begin{array}{l}\text { - Technical } \\
\text { compatibility }\end{array}$ & $\begin{array}{l}\text { - Adjustment of } \\
\text { maintenance } \\
\text { schedule } \\
\text { - Long-term facilitation } \\
\text { of trade }\end{array}$ & $\begin{array}{l}\text { - Technical } \\
\text { adjustment } \\
\text { - Elimination of } \\
\text { administrative } \\
\text { barriers }\end{array}$ \\
\hline $\begin{array}{l}\text { Electricity is difficult to } \\
\text { store and its demand } \\
\text { changes significantly }\end{array}$ & $\begin{array}{l}\text { • Energy } \\
\text { resource }\end{array}$ & $\begin{array}{l}\text { - Effective } \\
\text { management of } \\
\text { supply/demand }\end{array}$ & $\begin{array}{l}\text { - Exchange of surplus } \\
\text { electricity } \\
\text { - Efficient } \\
\text { management of } \\
\text { power } \\
\text { - Decreased ratio of } \\
\text { facility reserve }\end{array}$ & - Technical support \\
\hline
\end{tabular}

The details provided in Table 1 are as follows. First, the electricity system is characterized by a network system, so that electricity is exchanged under the structure of networks. This means that electrical power is transported through a wire in order to be both produced in a power plant and supplied to a final consumer. This indicates that the basic installation of an electricity grid and related infrastructure (interconnectors) is essential for electrical energy cooperation. Its attributes are related to the industrial structure. Additional installation of grid connections has the direct benefit of cooperation because it allows both the exporting and importing countries to exchange electricity at low cost and, ultimately, to reduce the cost of investment in power generation facilities. Further, the exchange of surplus electricity is increased. In the long term, it reduces the ratio of facility reserves. This is because policymakers who decide the overall energy-mix structure can consider using exchanged power instead of building new power plants. Furthermore, as the peak power times of countries are usually different, the decreased ratio of facility reserves provides plenty of opportunities to consider economic and political alternatives (Choubey 2014). Increased interconnections are also deemed as a means of responding to 
regional challenges related to energy security and climate change, particularly in the EU context (Sohn 2017). However, this is usually only possible with the increased cost of installations, as well as the increased cost of maintenance after the installations. Yet, the long-term benefits of energy cooperation are usually expected to outweigh the increased costs, but this characteristic, in itself, hinders cooperation initially (De Nooij 2011). Therefore, historically, the integration of power systems appears to have expanded from smaller regions to larger, or multilateral, regions.

Second, electricity has various technical characteristics depending on how it is generated. Electricity's technical nature varies depending on the energy source (gas, coal, nuclear, hydroelectric power, or renewables) and the specific technology. At the same time, the electricity system is greatly influenced by severe power outages or voltage fluctuations and their respective frequencies. When electricity supply and demand do not match, these problems are more severe and, in such instances, a great deal of damage can occur in households and industries. Thus, technical compatibility of electricity exchanges is required in each country. Cooperation through technical compatibility is essential for the consistent adjustment of maintenance schedules, which encourages the longterm facilitation of trade. However, technical compatibility forces a country to deal with a major policy coordination process, which also requires much discussion, and such discussion should be preceded by the elimination of administrative barriers.

Third, electricity is difficult to store. This peculiar aspect of electricity creates the condition that electrical power is mainly traded between geographically close countries. In addition, electricity has the characteristic that its demand varies greatly. This is a unique feature of electricity-its demand varies within not only an annual but also a daily cycle. Even if a lot of technical effort has been made worldwide to overcome these limitations of electrical power, the fact that produced power is difficult to store makes the problem even more difficult to solve.

Considering these characteristics, electricity energy cooperation requires multinational and regional institutions (Fuenfschilling and Truffer 2014; Puka and Szulecki 2014). Why do institutions matter in terms of electricity cooperation? First, technical support from functional institutions, such as TSOs and their networks, reduces potential inefficiencies. Specifically, TSOs have a primary role in maintaining the safe and reliable transmission of electricity, and they require technical support. The TSO networks not only encourage the basic functions of TSOs but also devise ways to manage much safer and more efficient goals together. Consequently, they investigate and sometimes 
suggest the technical schemes to fulfill their primary role. In the process of policy coordination among different states, regional institutions help to make multilateral electricity cooperation much more efficient.

Second, institutions play the role of coordinators. We examined the cooperation process in the electricity network interconnections through the functional network of institutions in the policy coordination process. Although the birth of electricity network interconnections seems to have been instigated by the momentum of a common policy based on the liberalization of the electricity market, cooperation had already been underway through the coordination process among various actors (Wallace 2010). Typically, these various actors included special energy regulators, TSOs, and the power exchanges. ${ }^{2}$ Among them, the networks between the TSOs were essential for both the energy union, which was aimed at the integrated electricity market, and for the establishment of the integrated electricity market. Moreover, the networks between the TSOs are a specific type of cooperation that is related to the level of the electricity network interconnections, which is highly influenced by the characteristics of cooperation within the electrical energy industry.

The TSOs ${ }^{3}$ deal with the power demand and equipment status of the power system in most European countries and play a key role in the operation of the electricity system and in the balancing of the market (Cameron 2007). At the same time, they play a role in the electricity system's development and provide comprehensive cooperation for electricity market integration (Henriot 2013). System operators should consider electricity's attributes as a network industry, including its various technological differences, storage difficulties, and severe fluctuations in demand. They also will have to be able to conduct their own actions by separating the networks into their component parts without considering the situation at the national level.

This cooperation of these institutions called TSOs became fully visible after the formation of the Florence Forum. Following the first legislative package, the Florence Forum was set up in 1998 as a gathering of stakeholders in the

\footnotetext{
${ }^{2}$ In terms of the industrial structure of electricity, there are the fields of regulatory agencies, transmission and grid operations, and electricity market exchanges, as well as the fields of electricity generation and distribution. However, the latter fields would be appropriate in trying to understand the integration of common regulatory guidelines because they lack the international policy coordination process of related actors.

${ }^{3}$ A TSO transmits electricity (electrical power) from generation plants over the electrical grid to regional or local electricity distribution operators. In the United States, there are similar functional institutions with such names as Independent System Operator (ISO) and Regional Transmission Organization (RTO).
} 
power industry (producers, power system operators [TSOs], consumers, traders, national coordinators, government officials, and the EC). This assembly did not yield much progress because of its lack of coercive ability. In the meantime, however, the EC was encouraged to continue establishing a pan-European operator network to expand the single internal power market in Europe. This led to the establishment of the European Transmission System Operations (ETSO) in 1999. ETSO has continued to increase its member system operators and related countries. In 1999, it comprised 32 operators in 15 EU member states, and also included Norway and Switzerland (Merlin 2005).

The process of cooperation intensified steadily with the increase in system operators, and it accelerated even more with the establishment of ENTSO-E. In Prague in June 2008, ENTSO-E was approved for the establishment of 36 European power grid operators. In December of that same year, a total of 42 TSOs signed the third legislative package on gas and electricity markets. According to ENTSO-E's Pilot Ten-Year Network Development Plan, ENTSO-E is responsible for the modeling of an integrated network, scenario development, national investment plans, and other matters (ENTSO-E 2010, 4).

\section{ELECTRICITY NETWORK INTERCONNECTIONS AND INSTITUTIONS IN EUROPE}

Europe is a region that has vigorously pursued regional integration and cooperation. Although there are some harbingers, which have obscured the future strength of integration and cooperation, it is without a doubt that Europe maintains the highest level of international integration and cooperation in many fields. Furthermore, when a field includes the action of working together for a common purpose and is not hampered by political events, such as in the hightechnology field, it is likely that the processes of integration and cooperation remain quite steady.

According to studies that have examined the EU regulatory policy-making process as a mode of European energy cooperation, the deepening process of energy cooperation has largely been possible since the 1990s. This period represents the time when the EU moved toward a single Internal Energy Market (IEM). The common energy policy of the EU revived the impetus for liberalization of the electricity market in 1996 (and the gas market in 1998) because such a regional movement was not previously in existence (Lee 2011). In retrospect of the EU's common energy policy process since 1946, the period after the 1990 s can be regarded as a resurgence period for a common energy policy, 
which had been lacking since the creation and development of the European Coal and Steel Community and Euratom (IEA 2014).

After 1996, the EU's three legislative packages required the unbundling of the power industry, which had had an uncompetitive structure at the national level. In addition, the form of unbundling has also been transformed into the operations characterized by independent operating institutions. Market openings have also increased, along with the evolution of the legislative packages. The IEM for a single power market was also able to be developed because the related special regulators had been empowered. However, this process of electricity energy cooperation can only be determined if we consider it as the process of a single market in Europe rather than as a process due to the characteristics of electricity (Young 2010).

The European 'electricity market' consists of wholesale markets and retail markets. The wholesale markets range from real-time balancing markets to long-term contracts. It includes different types of contracts or markets (longterm contracts, the forward and futures markets, the day-ahead market, the intra-day market, and the balancing market). In wholesale markets, electricity is sometimes traded privately between two parties. Also, it may be traded through a power exchange (energy exchange), which brings together more buyers and seller and offers transparent pricing (Erbach 2016).

Measuring exchange flows to analyze electricity network interconnections is important in that the variation in electricity network interconnections between countries becomes the dependent variable of this study, which will shed light on the role of institutions in the policy coordination of electricity networks. Such measures help the policies actually followed by one political actor to be considered by the actor's partners in order for them to realize their own individual objectives. The difference in energy and energy cooperation among countries in these regions can be gauged by measuring the degree of interconnections of the electricity networks between those countries. The intercountry electricity network interconnections are divided into two parts: the extent of inter-regional electricity installations (Dutton and Lockwood 2017) and the amount of electricity exchanged between countries. ${ }^{4}$ In this study, the latter

\footnotetext{
${ }^{4}$ First, electricity network interconnections can be measured by the extent of inter-regional electricity installations. A high number of installations means that electricity trading between countries can take place at a particular time and that it is mutually dependent on power policies and industrial sectors. Second, electricity network interconnections are measurable by the amount of inter-country power exchanges. A large amount of exchanges between countries means that there is a good infrastructure for electricity so that actual exchanges of electricity across borders are possible. Since the installation of production facilities takes time and the actual exchanges may not happen
} 
is regarded as the main dependent variable. ${ }^{5}$

Then, which factors will affect the interconnections of actual European electricity networks? What political and economic drivers influence the different levels of exchange flows between countries? First of all, the levels of interconnections are greater in geographically close regions due to the difficulty of storing electricity (Meisen and Mohammadi 2010). Actually, it is quite clear that electricity exchanges are common in neighboring countries. As electricity is difficult to store and its daily and annual demand changes significantly, a higher level of geographical proximity means that the possibility of effective electricity management increases. This characteristic is also discussed in Table 1. In addition, since economic losses increase as the exchange distances become longer, electricity's transmission distance is extremely important in the exchange. Therefore, the geographic factor has the greatest influence on the extent of electricity network interconnections.

Economic and industrial factors, such as country size and energy consumption, are also drivers affecting the interconnections of electricity networks. A large amount of energy consumption also requires a large supply and demand. In other words, there are many variables in terms of industrial structure and scale. At the same time, if the size of a country or the amount of energy consumption is large, the electricity exchange itself is likely to increase. For reference, in extant international political economy studies determining the drivers of international trade, insights from trade theory were applied in the study of IPE in relation to energy (Hughes and Lipscy 2013, 458) and similar factors were explained by the "gravity" model (Whitten and Kellstedt 2013, 214).

This study suggests that the interconnection of electricity networks can be achieved through past and present cooperation efforts, represented by both the integration process in the EU's common energy policy and the coordination process that has been managed by the former and current functional institutions of electricity. In many studies on international cooperation, institutions are an important variable analyzed when examining cooperation (Keohane 1988; Maggi 1999; Victor 2006). Dichotomous variables can also be utilized for

even after such installations are complete, it would be insufficient to measure actual interconnectedness in a given year. On the other hand, the amount of actual electricity exchange flows allows us to see the degree of network interconnections in that year.

5 'The exchange flow of transmission' includes all exchanges in various markets, even private exchanges between two parties (not through power exchanges). Moreover, the aggregate data of all exchange flows within the year indicate somewhat different dynamics other than what is shown in electricity markets. It was the study's primary reason for not ascribing too much to the 'electricity market' per se in the paper. These dynamics can be of interest to political scientists in particular. 
measurement.

First of all, the increase in general cooperation within the EU has meant the sharing and integration of common energy policies. This indicates that, the greater the familiarity and the stronger the experience of sharing common policies, the higher is the familiarity with the process of integration for other fields. Thus, this encourages the so-called spillover effect, which tends to vary depending on the level of the overall cooperation experience (Jordan 2001; Rosamond 2005). As we have seen earlier, to theorize energy cooperation the EC has made it possible to set up a market for electricity and related facilities based on electricity market liberalization policies negotiated among EU countries. Furthermore, this is likely to affect the level and extent of electricity network interconnections.

More importantly, the effects of energy cooperation on the coordination of functional institutions can be possible for electricity networks in particular. This statement is a result of the nature of electricity energy cooperation. As Table 1 shows, the benefits of electricity energy cooperation stem from the attributes of electricity and the necessary adjustment processes related to these attributes. Even in functional utility sectors, such as electricity transmission, policy coordination based on institutions matters (Fuenfschilling and Truffer 2014; Puka and Szulecki 2014; Tenggren, et al. 2016). According to the characteristics of energy cooperation, electricity is exchanged under the structure of networks and has various technical characteristics, depending on how it is generated. Each form has a particular policy coordination process related to installation costs, technical adjustments, and the elimination of administrative barriers.

However, the degree of energy interconnections and their strategies to develop such interconnections are different for each country. Furthermore, the experience of cooperation and interconnections of electricity networks in different regions of Europe also vary. Thus, there are still six different functional regions within ENTSO-E (North Sea, Baltic Sea, Central South, Continental South West, Continental South East, and Continental Central East). The network is divided according to system development, showing that the dynamics of energy cooperation are different in each region.

Apart from the above, other TSO networks have existed besides ETSO: the Association of the Transmission System Operators of Ireland (ATSOI), the Baltic Transmission System Operators (BALTSO), NORDEL (Association of TSOs from Norway, Finland, Denmark, Sweden, and Iceland), the Union for the Coordination of the Transmission of Electricity (UCTE), and the UK Transmission System Operators Association (UKTSOA). In particular, the system operator associations such as NORDEL and UCTE existed prior to the 
liberalization of the energy market in 1996. This implies that electricity energy cooperation can also start from the policy coordination between TSOs, with the exception of common regulatory energy policies. The experience under current and former cooperation in the form of TSO networks will be treated as an independent variable in the empirical section of this study and is expected to influence the level of electricity network interconnections (Roggenkamp and Boisseleau 2005; ENTSO-E 2010).

\section{RESEARCH DESIGN AND HYPOTHESES}

The level of electricity network interconnections varies depending on a variety of factors. In practice, common energy policies across Europe continue to be integrated, but there are still specific differences between countries and subregions. As seen above, the subject of this study is European electricity network interconnections, which are the sum of the exchange flows between two countries in a given year. ${ }^{6}$ This information is used to determine the extent of electricity network interconnections, which represents the dependent variable.

The data used here represent 41 countries/regions ${ }^{7}$ in Europe in 2013. ${ }^{8}$ As electricity demand changes dramatically, both daily and seasonally, this study utilizes yearly data to look at the overall trends of the exchanges. Moreover, by using relatively recent data, this study can capture the current state of European electricity network interconnections. Since the trend towards greater electricity trading has not changed dramatically, this approach is not a serious problem.

The dependent variable and most of the key independent variables are based on the 2013 data from ENTSO-E (2014). Table 2 below explains the sources of each variable, as well as the operational independent variables, in order to understand the specific dynamics of electricity network interconnections. All

\footnotetext{
${ }^{6}$ The 'network' usually refers to a system of lines, wires, etc., that are connected to each other. In this study, a system of electricity exchange flows is considered as an 'electricity network.' As mentioned earlier, a system of electricity grid installations is another type of 'electricity network.' As this study seeks to explain the variation of exchange flows - the degree of interconnections in one type of electricity network - the term 'electricity network interconnections' is used.

7 The reason for using "country/region" is that ENTSO-E data also includes Northern Ireland and Ukraine West, which are not strictly countries, but rather regions within certain countries.

${ }^{8}$ As of 2014, ENTSO-E consists of a total of 35 countries/regions. The ENTSO-E data also include additional data from eight countries, which are not member countries/regions, but are located adjacent to members. On the other hand, members who are island countries and without electricity exchanges with neighboring countries (i.e., Cyprus, Malta, and Iceland), are excluded from the analysis.
} 
variables in this study were based on dyadic data. This comes from the nature of the study, which is to explore the differences in the levels of electricity energy cooperation. The study uses cross-sectional multivariate linear regression analysis. Cross-sectional analysis will effectively show the main drivers of the differences in the pair data.

When neighboring countries are bordered by land and the amount of power consumption is controlled for in the two countries that exchange electricity, three types of cooperation experiences are included in this study: current electricity energy cooperation experience, former electricity energy cooperation experience, and cooperation experience in the region. This is because the main purpose of this study is to shed light on how the cooperation experience is influenced by these three factors.

First of all, the current electricity energy cooperation experience can be divided into six functional regions for the development of the system under ENTSO-E; namely, the North Sea Region, the Baltic Sea Region, the Continental Central South Region, the Continental South West Region, the Continental South East Region, and the Continental Central East Region. The variable Current Electricity Energy Cooperation Experience is a dichotomous variable that shows whether or not there is prior experience in the current functional ENTSO-E region. In order to examine the specific regional characteristics, each functional region is presented as a single variable in the analysis. The following Hypothesis 1 is intended to analyze how current experiences of mutual cooperation affect the actual interconnections of electricity networks.

Hypothesis 1: The level of electricity network interconnections was more likely to be higher when both countries belonged to the same functional region of ENTSO-E.

Next, cooperation through the former functional institutions is examined. The following are examples of former functional authorities: ATSOI, BALTSO, ETSO, NORDEL, UCTE, and UKTSOA, ${ }^{9}$ which can be deemed as one type of functional institution. All become components for the variable Former Electricity Energy Cooperation Experience. This is a dichotomous variable to determine whether or not a pair of countries has past experience in electricity networks. The following Hypothesis 2 is used to analyze the effects of previous experiences of energy cooperation based on actual electricity networks.

\footnotetext{
${ }^{9}$ The UKTSOA (UK Transmission System Operators Association) is excluded from the analysis because it represents electricity cooperation within a state, not international cooperation.
} 
Table 2. Explanation and Data Sources for Variable Measurements Related to Electricity Network Interconnections

\begin{tabular}{|c|c|c|c|}
\hline Variables & Measurement and Data Source & Unit & $\begin{array}{l}\text { Variable } \\
\text { Type }\end{array}$ \\
\hline \multicolumn{4}{|c|}{ Dependent Variable } \\
\hline $\begin{array}{l}\text { Level of Electricity Network } \\
\text { Interconnections }\end{array}$ & $\begin{array}{l}\text { The amounts of power exchange flows in/out are } \\
\text { summed up over a country pair. } \\
\text { - Detailed, harmonized level can be checked } \\
\text { through ENTSO-E database. }\end{array}$ & GWh & $\begin{array}{l}\text { Continuous } \\
\text { Variable }\end{array}$ \\
\hline \multicolumn{4}{|c|}{ Independent Variable } \\
\hline Neighboring Country & $\begin{array}{l}\text { If the pair of countries is bordered by land, it is } \\
\text { marked as } 1 \text { (attached) or } 0 \text { (separated). } \\
\text { - The authors fill up the data based on the map } \\
\text { of Europe. }\end{array}$ & - & $\begin{array}{c}\text { Dichotomous } \\
\text { Variable }\end{array}$ \\
\hline Electricity Consumption & $\begin{array}{l}\text { Electricity consumptions in } 2013 \text { for each country } \\
\text { of a country pair are summed up. } \\
\text { - Data are from the yearly energy data for } 2013 \\
\text { of ENTSO-E. } \\
\text { - The authors also use EIA's } 2013 \text { International } \\
\text { Energy Statistics data for those who are not } \\
\text { members of ENTSO-E. }\end{array}$ & TWh & $\begin{array}{l}\text { Continuous } \\
\text { Variable }\end{array}$ \\
\hline $\begin{array}{l}\text { Current Electricity Energy } \\
\text { Cooperation Experience }\end{array}$ & $\begin{array}{l}\text { If both countries of a country pair belong to } \\
\text { the same functional regions of ENTSO-E, } \\
\text { it is marked as } 1 \text { (experienced) or } 0 \text { (non- } \\
\text { experienced). } \\
\text { - The authors fill up the data based on the } \\
\text { homepage of ENTSO-E. }\end{array}$ & & $\begin{array}{c}\text { Dichotomous } \\
\text { Variable }\end{array}$ \\
\hline $\begin{array}{l}\text { Former Electricity Energy } \\
\text { Cooperation Experience }\end{array}$ & $\begin{array}{l}\text { If both countries of a country pair were members } \\
\text { of any form of TSOs other than ENTSO-E, } \\
\text { it is marked as } 1 \text { (experienced) or } 0 \text { (non- } \\
\text { experienced). } \\
\text { - The authors fill up the data based on the } \\
\text { homepage of ENTSO-E. }\end{array}$ & - & $\begin{array}{c}\text { Dichotomous } \\
\text { Variable }\end{array}$ \\
\hline $\begin{array}{l}\text { Cooperation Experience } \\
\text { in the Region }\end{array}$ & $\begin{array}{l}\text { If both countries of a country pair are members } \\
\text { of the EU, it is marked as } 1 \text { (experienced) or } 0 \\
\text { (non-experienced). } \\
\text { - The authors fill up the data based on the } \\
\text { information of Eurostat. }\end{array}$ & - & $\begin{array}{l}\text { Dichotomous } \\
\text { Variable }\end{array}$ \\
\hline $\begin{array}{l}\text { Level of Cooperation } \\
\text { Experience in the Region }\end{array}$ & $\begin{array}{l}\text { If both countries of a country pair are members } \\
\text { of the EU, the number of years each country } \\
\text { belonged to the EU as of } 2013 \text { is summed up. } \\
\text { - The authors fill up the data based on the } \\
\text { information of Eurostat. }\end{array}$ & Year & $\begin{array}{l}\text { Continuous } \\
\text { Variable }\end{array}$ \\
\hline
\end{tabular}

Source: EIA International Energy Statistics (https://www.eia.gov/electricity/data.cfm) ENTSO-E (https://www.entsoe.eu), Eurostat (http://ec.europa.eu/eurostat) 
Hypothesis 2: The level of electricity network interconnections was more likely to be higher if both countries were members of the same former TSO network.

Finally, there is a supranational organization called the EU. To determine how EU regional institutions affect the current interconnections of electricity networks, this study suggests operationalizing variables such as Cooperation Experience in the Region and Level of Cooperation Experience in the Region. Unlike the former variable, which is a dichotomous variable indicating whether or not a country pair belongs to the EU, the latter variable is a continuous variable with additional information about whether or not both countries are members of the EU. The following Hypothesis 3 is intended to analyze how the cooperation experiences through the EU affect the current levels of electricity network cooperation.

Hypothesis 3: The level of electricity network interconnections was more likely to be higher if both countries belonged to the EU.

Table 6 in the Appendix is a simple table of descriptive statistics for both dependent and independent variables. As can be seen in Table 6, there are 820 observations in terms of viewing pair data for 41 countries/regions in Europe.

\section{RESEARCH ANALYSIS}

This empirical analysis is based on a total of 16 models used to find the factors that determine the different levels of electricity exchange flows in the electricity interconnection networks between European countries. All of the models use cross-sectional multivariate linear regression. The reason for dividing the models is not derived from the characteristics of the data but is an attempt to provide a multidimensional view of the independent variables of the "cooperation experience." Models 1 to 7 in Table 3 are for testing Hypothesis 1, models 8 to 14 in Table 4 are for testing Hypothesis 2, and, models 15 and 16 in Table 5 are for testing Hypothesis 3.

For all models, the Neighboring Country and Electricity Consumption as control variables were statistically significant when the degrees of cooperation experience were controlled for within the confidence level of 95 percent. The concrete confidence levels varied based on the models-in particular, in Table 5, the Electricity Consumption in model 16 is statistically significant within 
the confidence level of 90 percent. Neighboring Country shows how much the electricity exchange (GWh) will increase on average when the other variables are controlled for when two countries border each other. Electricity Consumption represents how much the unit of electricity consumption (TWh) of a country pair increases on average when the other variables are controlled for. There is a difference in the control variables in models 1 to 7 and between models 8 and 10 through 16, in which the Current Electricity Energy Cooperation Experience is also controlled for. This is to show how the past experience of electricity cooperation and the cooperation experience in the region through the EU can influence the level of electricity network interconnections when controlling for the ongoing cooperation experience.

Table 3 shows the correlations to other factors of the interconnection levels in the functional regions of the current ENTSO-E. Model 1 shows statistical significance within the confidence level of 99 percent for the current cooperative experience. Also, on average the interconnection levels in the regions mentioned show an increase in the electricity exchange of $470.8 \mathrm{GWh}$ when other variables are controlled for. Models 2 through 7 analyzed the effect of the current regional electricity energy cooperation experience on the level of electricity network interconnections. Models 2 and 5, which show the effects of current cooperation in the North Sea Region and the Continental South West Region, were statistically significant within a confidence level of 99 percent. On the other hand, models 3 and 6, which include variables for current energy cooperation in the Baltic Region and the Continental South East Region, show a positive correlation within the 95 percent confidence level. Lastly, models 4 and 7 show that the influence of current cooperation in the Continental Central South Region and the Continental Central East Region are not statistically significant, even within the confidence level of 90 percent.

Table 4 shows the correlation between the electricity energy cooperation experience through former functional institutions and the level of exchange flows in the current ENTSO-E. Model 8 shows that, when the variable Current Electricity Energy Cooperation Experience is controlled for, the Former Electricity Energy Cooperation Experience is not statistically significant within the confidence level of 90 percent. On the other hand, model 9 shows the statistical significance of this variable within the confidence level of 95 percent, when the variable regarding the current electricity energy cooperation experience is not controlled for. When both countries were members of former TSO networks, the average increase in electricity exchanges was 206.9 GWh, when controlling for other variables.

Models 10 to 14 analyze the impact of former cooperation experiences on 
electricity network interconnection levels. Model 13 shows the effect of the cooperation experience of past NORDEL membership, which is positive and statistically significant within the confidence level of 99 percent. Models 10 and 12 show the effects of former associations with ATSOI and ETSO on electricity network cooperation, which is statistically significant within the confidence level of 90 percent. However, the ATSOI variable shows a negative correlation with the dependent variable. Models 11 and 14 were intended to show the effects of former cooperation experiences when country pairs belong to BALTSO and UCTE, respectively, but they were not statistically significant, even within the

Table 3. Functional Regions under ENTSO-E and Factors of Electricity Network Interconnections

\begin{tabular}{|c|c|c|c|c|c|c|c|}
\hline Variables & Model 1 & Model 2 & Model 3 & Model 4 & Model 5 & Model 6 & Model 7 \\
\hline Neighboring Country & $\begin{array}{c}2902.5^{\star * *} \\
(185.3)\end{array}$ & $\begin{array}{c}3098.1^{* * *} \\
(172.7)\end{array}$ & $\begin{array}{c}3133.6^{* * *} \\
(173.9)\end{array}$ & $\begin{array}{c}3129.5^{* * *} \\
(179.0)\end{array}$ & $\begin{array}{c}3105.7^{* * *} \\
(174.2)\end{array}$ & $\begin{array}{c}3070.2^{* * *} \\
(179.0)\end{array}$ & $\begin{array}{l}3235.2^{* * *} \\
(179.4)\end{array}$ \\
\hline $\begin{array}{l}\text { Electricity } \\
\text { Consumption }\end{array}$ & $\begin{array}{l}0.559^{* * *} \\
(0.193)\end{array}$ & $\begin{array}{l}0.465^{\star *} \\
(0.194)\end{array}$ & $\begin{array}{l}0.554^{* * *} \\
(0.195)\end{array}$ & $\begin{array}{l}0.563^{* * *} \\
(0.195)\end{array}$ & $\begin{array}{l}0.521^{* * *} \\
(0.195)\end{array}$ & $\begin{array}{l}0.510^{* * *} \\
(0.196)\end{array}$ & $\begin{array}{l}0.514^{* * *} \\
(0.197)\end{array}$ \\
\hline $\begin{array}{l}\text { Current Electricity } \\
\text { Energy Cooperation } \\
\text { Experience }\end{array}$ & $\begin{array}{c}470.8^{* * *} \\
(122.3)\end{array}$ & - & - & - & - & - & - \\
\hline North Sea Region & - & $\begin{array}{l}875.1^{* * *} \\
(208.2)\end{array}$ & - & - & - & - & - \\
\hline Baltic Sea Region & - & - & $\begin{array}{l}490.0 * * \\
(231.4)\end{array}$ & - & - & - & - \\
\hline $\begin{array}{l}\text { Continental Central } \\
\text { South Region }\end{array}$ & - & - & - & $\begin{array}{c}198.7 \\
(238.2)\end{array}$ & - & - & - \\
\hline $\begin{array}{l}\text { Continental South West } \\
\text { Region }\end{array}$ & - & - & - & - & $\begin{array}{c}2214.6^{* * *} \\
(789.1)\end{array}$ & - & - \\
\hline $\begin{array}{l}\text { Continental South East } \\
\text { Region }\end{array}$ & - & - & - & - & - & $\begin{array}{l}660.3^{* *} \\
(311.9)\end{array}$ & - \\
\hline $\begin{array}{l}\text { Continental Central } \\
\text { East Region }\end{array}$ & - & - & - & - & - & - & $\begin{array}{l}-299.3 \\
(196.9)\end{array}$ \\
\hline Intercept & $\begin{array}{c}-148.3^{* *} \\
(67.70)\end{array}$ & $\begin{array}{l}-88.58 \\
(64.39)\end{array}$ & $\begin{array}{l}-84.86 \\
(65.26)\end{array}$ & $\begin{array}{l}-73.67 \\
(65.38)\end{array}$ & $\begin{array}{l}-61.85 \\
(64.58)\end{array}$ & $\begin{array}{l}-65.17 \\
(64.70)\end{array}$ & $\begin{array}{l}-42.63 \\
(66.68)\end{array}$ \\
\hline $\mathbf{N}$ & 820 & 820 & 820 & 820 & 820 & 820 & 820 \\
\hline $\mathbf{R}^{2}$ & 0.315 & 0.317 & 0.306 & 0.303 & 0.309 & 0.306 & 0.304 \\
\hline Adj. $R^{2}$ & 0.312 & 0.315 & 0.304 & 0.300 & 0.307 & 0.304 & 0.302 \\
\hline
\end{tabular}

Note: ${ }^{* * *} \mathrm{p}\left\langle 0.01,{ }^{* *} \mathrm{p}\left\langle 0.05,{ }^{*} \mathrm{p}<0.1\right.\right.$. Two-tailed tests. Numbers in parentheses indicate standard errors. 
confidence level of 90 percent.

Table 5 shows the correlation of the Cooperation Experience in the Region and the Level of Cooperation Experience in the Region with the Level of Electricity Network Interconnections. Models 15 and 16 show that belonging to the EU and the length of time as a member both affect the current level of electricity network interconnections (when the current electricity energy cooperation experience is controlled for). According to these parameters, the statistical results of both models 15 and 16 show statistical significance within the confidence level of 99 percent. The results of model 15 tell us that, when both countries in a pair belong

Table 4. Former TSOs and Factors of Electricity Network Interconnections

\begin{tabular}{|c|c|c|c|c|c|c|c|}
\hline Variables & Model 8 & Model 9 & Model 10 & Model 11 & Model 12 & Model 13 & Model 14 \\
\hline Neighboring Country & $\begin{array}{c}2888.1^{* * *} \\
(186.3)\end{array}$ & $\begin{array}{c}3084.9^{* * *} \\
(178.0)\end{array}$ & $\begin{array}{c}2938.7^{* * *} \\
(186.0)\end{array}$ & $\begin{array}{c}2898.7^{* * *} \\
(186.3)\end{array}$ & $\begin{array}{c}2918.4^{\star \star *} \\
(185.2)\end{array}$ & $\begin{array}{c}2844.2^{\star * \star} \\
(184.2)\end{array}$ & $\begin{array}{c}2901.1^{* \star *} \\
(185.7)\end{array}$ \\
\hline $\begin{array}{l}\text { Electricity } \\
\text { Consumption }\end{array}$ & $\begin{array}{c}0.567^{* * *} \\
(0.194)\end{array}$ & $\begin{array}{c}0.577^{* * *} \\
(0.194)\end{array}$ & $\begin{array}{c}0.545^{* * *} \\
(0.193)\end{array}$ & $\begin{array}{c}0.562^{* * *} \\
(0.194)\end{array}$ & $\begin{array}{c}0.520^{* * *} \\
(0.194)\end{array}$ & $\begin{array}{c}0.577^{* * *} \\
(0.192)\end{array}$ & $\begin{array}{c}0.560^{* * *} \\
(0.194)\end{array}$ \\
\hline $\begin{array}{l}\text { Current Electricity } \\
\text { Energy Cooperation } \\
\text { Experience }\end{array}$ & $\begin{array}{c}437.6^{* * *} \\
(129.7)\end{array}$ & - & $\begin{array}{c}476.4^{* * *} \\
(122.2)\end{array}$ & $\begin{array}{c}468.9^{* * *} \\
(122.7)\end{array}$ & $\begin{array}{c}399.2^{* * *} \\
(127.7)\end{array}$ & $\begin{array}{l}410.4^{* * *} \\
(122.2)\end{array}$ & $\begin{array}{c}466.3^{* \star *} \\
(128.2)\end{array}$ \\
\hline $\begin{array}{l}\text { Former Electricity } \\
\text { Energy Cooperation } \\
\text { Experience }\end{array}$ & $\begin{array}{c}84.28 \\
(109.6)\end{array}$ & $\begin{array}{l}206.9^{* *} \\
(104.0)\end{array}$ & - & - & - & - & - \\
\hline ATSOI & - & - & $\begin{array}{c}-2556.0^{*} \\
(1353.6)\end{array}$ & - & - & - & - \\
\hline BALTSO & - & - & - & $\begin{array}{c}161.9 \\
(788.2)\end{array}$ & - & - & - \\
\hline ETSO & - & - & - & - & $\begin{array}{l}200.6^{*} \\
(104.5)\end{array}$ & - & - \\
\hline NORDEL & - & - & - & - & - & $\begin{array}{c}2215.7^{\star * *} \\
(544.9)\end{array}$ & - \\
\hline UCTE & - & - & - & - & - & - & $\begin{array}{c}12.76 \\
(108.3)\end{array}$ \\
\hline Intercept & $\begin{array}{c}-168.7^{* *} \\
(72.70)\end{array}$ & $\begin{array}{l}-130.8 \\
(72.29)\end{array}$ & $\begin{array}{c}-146.2^{* *} \\
(67.60)\end{array}$ & $\begin{array}{c}-148.8^{* *} \\
(67.77)\end{array}$ & $\begin{array}{c}-192.8^{* * *} \\
(71.46)\end{array}$ & $\begin{array}{c}-150.7^{* *} \\
(67.09)\end{array}$ & $\begin{array}{c}-151.3^{* *} \\
(72.43)\end{array}$ \\
\hline $\mathbf{N}$ & 820 & 820 & 820 & 820 & 820 & 820 & 820 \\
\hline $\mathbf{R}^{2}$ & 0.315 & 0.306 & 0.318 & 0.315 & 0.318 & 0.328 & 0.315 \\
\hline Adj. $R^{2}$ & 0.312 & 0.303 & 0.315 & 0.312 & 0.315 & 0.325 & 0.312 \\
\hline
\end{tabular}

Note: ${ }^{* * *} p<0.01,{ }^{* *} p<0.05,{ }^{*} p<0.1$. Two-tailed tests. Numbers in parentheses indicate standard errors. 
to the EU, there is likely to be an increase in the electricity exchanges of $\mathbf{2 5 2 . 2}$ GWh on average, when other variables are controlled for. Model 16 shows that an increase of one year in the EU for the two countries correlates with a 6.048 GWh increase in electricity exchanges, on average, when other variables are controlled for.

Table 5. Cooperation Experience in the Region and Factors of Electricity Network Interconnections

\begin{tabular}{lcc}
\hline \multicolumn{1}{c}{ Variables } & Model 15 & Model 16 \\
\hline Neighboring Country & $2937.0^{* * *}$ & $2982.7^{* * *}$ \\
& $(185.1)$ & $(185.6)$ \\
Electricity Consumption & $0.563^{* * *}$ & $0.367^{*}$ \\
Current Electricity Energy Cooperation & $(0.193)$ & $(0.200)$ \\
Experience & $376.8^{* * *}$ & $363.8^{* * *}$ \\
Cooperation Experience in the Region & $(127.4)$ & $(125.5)$ \\
& $252.2^{* *}$ & - \\
Level of Cooperation Experience in the Region & $(98.84)$ & $6.048^{* * *}$ \\
& & $(1.771)$ \\
Intercept & - & $-307.4^{* * *}$ \\
$\mathbf{N}$ & $-239.4^{* * *}$ & $(81.82)$ \\
$\mathbf{R}^{2}$ & $(76.33)$ & 820 \\
Adj. $\mathbf{R}^{2}$ & 820 & 0.325 \\
\hline Note: ${ }^{* * *} p\left\langle 0.01,{ }^{* *} p\left\langle 0.05,{ }^{*} p\langle 0.1\right.\right.$ Two-tailed tests. Numbers in parentheses indicate standard errors.
\end{tabular}

\section{DISCUSSION}

The analysis of Table 3, Table 4, and Table 5 are as follows. First, it is possible to see that the aforementioned hypotheses are all accepted in a broad sense. In other words, various cooperation experiences in Europe have worked positively under the condition that other geographical and economic variables are controlled for (models 1, 9, 15, and 16). However, when each model is specifically examined, there are differences visible in the general trends.

According to model 1, which was supposed to test Hypothesis 1, it was possible to conclude that the level of electricity network interconnections was more likely to be higher, currently, when both countries belonged to the same 
functional region within ENTSO-E. However, there was no positive effect on the current cooperation experience for the Continental Central South Region and the Continental Central East Region (models 4 and 7). On the other hand, belonging to other regions was positively correlated with the actual level of exchange flows. This result was due to the fact that the intentions or strategies of the interconnections were different in each country, resulting in variations in the level of cooperation and in the experiences of each sub-region in Europe in terms of system development. In other words, this shows that the dynamics of the policy coordination process through the same institutions today and the form of electricity energy cooperation can be different within the same region. Indeed, in the southwest of Europe (including the Iberian Peninsula), there have been many regional investments to harness the power of wind, solar, and hydro energy sources, and these huge investments have aimed to integrate renewable energy into the power system (ENTSO-E 2010). The positive correlation between the regional cooperation experiences and the actual electricity exchanges is shown in model 5 .

By looking at models 8 to 14, Hypothesis 2-the level of electricity network interconnections is more likely to be higher if both countries were past members of the same TSO-can be tested and partially accepted. In model 9 , which controls for the current experience of energy cooperation, there was no valid statistical significance. This seems to show the limits of measuring past and current cooperation experiences through only a dichotomous variable. However, in the models that included NORDEL and ETSO, respectively, it was possible to get the result that the level of electricity network interconnections was intensified, even when the present cooperation experience was controlled for. In fact, NORDEL and ETSO are two of the oldest networks in terms of electricity system operations (established in 1951 and 1963, respectively). As a result, there have been higher levels of the cooperation experience, and of the policy coordination process, including the installation of infrastructure, technological adjustments, and the elimination of administrative obstacles. On the other hand, being a member of ATSOI has had a negative effect on the level of interconnections. This seems to be due to the lack of policy coordination for this electricity system, since the electricity exchanges between Northern Ireland and Ireland and the UK initially encountered higher installation costs, as a result of geographical obstacles, and there appeared to have been limited attempts to overcome these obstacles.

Particular attention should be paid to NORDEL and its former member countries (Pineau et al. 2004; Cameron 2007). In terms of the member countries of NORDEL-Denmark, Finland, Iceland, Norway, and Sweden-there have 
been many related policy coordination processes. All of the policy coordination processes, such as the installation of facilities, technical adjustment and support, and the elimination of administrative obstacles, have been actively conducted. This is also particularly true in countries where congestion is handled best, thanks to their attempts to eliminate administrative barriers concerning technical compatibility. These countries have a high percentage of renewable energy in their energy mix, which historically has facilitated the coordination process. At the same time, social approval of transmissions and related cooperation has also had a major influence. Under such conditions, related investment facilities have been actively promoted within the regions (NORDEL 2009; ENTSO-E 2010). ${ }^{10}$

Lastly, Hypothesis 3 is analyzed using models 15 and 16. Both results strengthen the argument that the level of electricity network interconnections was more likely to be higher if both countries belonged to the EU, and vice versa. In particular, the levels of electricity network interconnections were intensified through the active and common energy policies of the EU. Model 16 also shows that interconnection levels have a tendency to increase with the level of general cooperation experience in the EU. This was possible because the process of social integration, and the experience of sharing a common policy, also facilitated electricity exchanges.

According to the EC, the European regulatory framework must be fully implemented and applied. The EC believes that a "solid regulatory framework is a prerequisite for the necessary infrastructure investments to happen." For such necessities, the trans-European energy networks' Regulation (TEN-E) is addressed for the first time for "the specific issue of projects that cross borders or that have an impact on cross-border flows" (European Commission 2015a, 9).

${ }^{10}$ Countries in the North Sea Region are ready to implement the North Sea National Offshore Grid Initiative (NSCOGI) through a 2010 Memorandum of Understanding to meet their renewable energy targets. Grid implementation has preceded such goals. This initiative is centered on ten countries, including five former NORDEL countries. 


\section{CONCLUSION}

The European region has accelerated the intensity of its cooperation efforts since the establishment of the EU. Energy cooperation represented by not only the harmonization of technical and institutional standards of power systems and transnational energy markets but also the intensification of energy-related network interconnections have grown. In terms of the various kinds of energy cooperation, this study highlights the electricity network interconnections and their political and economic drivers for influencing the different levels of exchange flows between countries.

After defining energy cooperation, this study evaluated European energy cooperation, particularly in terms of electricity transmission network integration. The regional scope of the study was Europe and the unit of analysis was European country pairs. In order to show the variations in electricity energy cooperation, the study first looked at the characteristics of electrical energy cooperation. This became the background for the study's later empirical analysis. Second, the regression analysis examined the factors that mattered in electricity flow exchanges. Multivariate regression analysis using cross-sectional dyadic data showed that the level of historical policy coordination of regional TSOs was positively associated with (TSO) networks and current exchange flows. Throughout the different model specifications, having experience of the same institution was likely to increase the propensity of dyadic electricity exchange flows. In addition to the initial intuitions about geographical connectivity and power consumption, current and former cooperation through electricity institutions influenced the degree of different regional interconnections, even within Europe.

The results of the hypotheses tested in this study have several implications. First, by examining European electricity network interconnections, the discussion throughout the study broadens our knowledge of cooperation, including energy cooperation, in international political economy. While a number of international political economy studies have focused on various sectors that govern global energy, particular attention to electricity-related networks has been rare.

Specifically, the findings from the empirical analysis provide policy implications both for regions that have networks for electricity energy cooperation and those that do not. For the former regions, the positive association between exchange flows and historical and current policy coordination through TSO networks implies that measures to facilitate such networks are necessary for actual electricity network interconnections. Next, 
for other regions, such as East Asia, related institutions can be an initial step if, in particular, they seek ways to encourage regional functional cooperation concerning electricity. This implies that those countries and regions that would increase electricity flows, such as those in East Asia, need to establish and work with effective institutions for coordination. Setting up electricity cooperation institutions in East Asia would enable participating countries to estimate the costs and benefits, to make potential cooperation plans, to overcome political and economic hurdles, and to implement plans for mutual benefits in the region.

In this study, however, examining the interconnections through the degree of installations of inter-regional electricity facilities was not fully conducted. Institutions matter. However, not all institutions increase electricity exchange flows. This study's multivariate models suggest that countries that are members of institutions that have a longer history of cooperation (e.g. NORDEL) are likely to increase electricity flows. In addition to longevity, future case studies of the conditions under which institutions successfully coordinate cooperation would be a good attempt to understand this dynamic. An empirical analysis of the various forms of energy cooperation based on the European region is greatly encouraged. Moreover, studies on understanding how European electricity network interconnections could be developed further through other variables that affect network interconnections and electricity exchanges also merit support.

\section{REFERENCES}

Bättig, Michèle B. and Thomas Bernauer. 2009. "National Institutions and Global Public Goods: Are Democracies More Cooperative in Climate Change Policy?” International Organization 63(2), 281-308.

Buchan, David. 2015. "Energy Policy-Sharp Challenges and Rising Ambitions.” In Mark A. Pollack, Alasdair Young, and Helen Wallace eds., Policy-Making in the European Union. New York: Oxford University Press, 344-366.

Cameron, Peter D. 2007. Competition in Energy Markets: Law and Regulation in the European Union. New York: Oxford University Press.

Casier, Tom. 2011. "The Rise of Energy to the Top of the EU-Russia Agenda: From Interdependence to Dependence?” Geopolitics 16(3), 536-552.

Choubey, Sourav. 2014. "Literature Survey on Cross Border Power Trading." International Journal of Electronic and Electrical Engineering 7(4), 401-406. 
De Nooij, Michiel. 2011. "Social Cost-Benefit Analysis of Electricity Interconnector Investment: A Critical Appraisal.” Energy Policy 39(6), 3096-3105.

Dutton, Joseph and Matthew Lockwood. 2017. "Ideas, Institutions and Interests in the Politics of Cross-Border Electricity Interconnection: Greenlink, Britain and Ireland." Energy Policy 105, 375-385.

ENTSO-E. 2010. "ENTSO-E's Pilot Ten-Year Network Development Plan." Accessed at https://www.entsoe.eu/major-projects/ten-year-networkdevelopment-plan/general/Pages/default.aspx (November 20, 2017) . 2015. "ENTSO-E Statistical Factsheet 2014." Accessed at https://www. entsoe.eu/Documents/Publications/Statistics/ Factsheet/entsoe_ sfs2014_web.pdf (November 20, 2017)

. 2014. "ENTSO-E Yearly Statistics \& Adequacy Retrospect 2013." Accessed at https://www.entsoe.eu/Documents/Publications/ Statistics/YSAR/141515_YSAR_2013_report.pdf (November 20, 2017)

Erbach, Gregor. 2016. "Understanding Electricity Markets in the EU." European Parliamentary Research Service. Accessed at http://www. europarl.europa.eu/RegData/etudes/-BRIE/2016/593519/EPRS_ BRI(2016)593519_EN.pdf. (November 14, 2017).

European Commission. 2015a. "Achieving the 10\% Electricity Interconnection Target-Making Europe's Electricity Grid Fit for 2020.” COM 82 (final). Brussels: European Commission.

. 2015b. "A Framework Strategy for a Resilient Energy Union with a Forward-Looking Climate Change Policy." COM 80 (final). Brussels: European Commision.

Fuenfschilling, Lea and Bernhard Truffer. 2014. "The Structuration of SocioTechnical Regimes-Conceptual Foundations from Institutional Theory." Research Policy 43(3), 772-791.

Henriot, Arthur. 2013. "Financing Investment in the European Electricity Transmission Network: Consequences on Long-Term Sustainability of the TSOs Financial Structure." Energy Policy 62, 821-829.

Hughes, Llewelyn and Phillip Y. Lipscy. 2013. "The Politics of Energy." Annual Review of Political Science 16, 449-469.

IEA. 2014. "European Union 2014 Review." Energy Policies of IEA Countries. Accessed at https://www.iea.org/publications/freepublications/ publication/EuropeanUnion_2014.pdf (November 20, 2017)

Jordan, Andrew. 2001. "The European Union: An Evolving System of MultiLevel Governance... Or Government?” Policy \& Politics 29(2), 193-208. Keohane, Robert O. 1988. "International Institutions: Two Approaches." 
International Studies Quarterly 32(4), 379-396. . 2005. After Hegemony: Cooperation and Discord in the World Political Economy. Princeton: Princeton University Press.

Korean Power Exchange. 2011. World Power Market Trend-European Union. Seoul: Korean Power Exchange (KPX).

Lee, Jae-Seung. 2007. "Issues and Approaches in Northeast Asian Energy Cooperation: Agenda-Setting in International Political Economy." Journal of Korean Politics 16(2), 137-164. . 2011. "The Evolution of EU's Common Energy Policy." Journal of International Politics 16(1), 31-68.

Maggi, Giovanni. 1999. "The Role of Multilateral Institutions in International Trade Cooperation." American Economic Review 89(1), 190-214.

Meisen, Peter and Charezade Mohammadi. 2010. "Cross-Border Interconnections on Every Continent." Accessed at https://www.geni. org/globalenergy/research/cross-border-interconnections/CrossBor-der\%2oInterconnections\%20on\%2oEvery\%2oContinent.pdf. (November 14, 2017).

Merlin, Andrè. 2005. "An Overview from Electricity Transimission System's Operator's Perspective.” European Review of Energy Markets 1(1), 159175 .

Nicolas, Francoise. 2009. "ASEAN Energy Cooperation: An Increasingly Daunting Challenge.” Accessed at https://www.ifri.org/en/publications/ enotes/notes-de-lifri/asean-energy-cooperation-increasinglydaunting-challenge\#sthash.TAOVU3Qk.dpbs (November 20, 2017)

Parisio, Lucia and Bruno Bosco. 2008. "Electricity Prices and Cross-Border Trade: Volume and Strategy Effects." Energy Economics 30(4), 17601775 .

Pineau, Pierre-Olivier, Anil Hira and Karl Froschauer. 2004. "Measuring International Electricity Integration: A Comparative Study Ofthe Power Systems under the Nordic Council, MERCOSUR, and NAFTA.” Energy Policy 32(13), 1457-1475.

Puka, Lidia and Kacper Szulecki. 2014. "The Politics and Economics of CrossBorder Electricity Infrastructure: A Framework for Analysis.” Energy Research \& Social Science 4, 124-134.

Roggenkamp, Martha and François Boisseleau. 2005. "The Liberalisation of the EU Electricity Market and the Role of Power Exchanges." In Martha Roggenkamp and François Boisseleau eds., The Regulation of Power Exchanges in Europe. Oxford: Intersentia, 1-29.

Rosamond, Ben. 2005. "The Uniting of Europe and the Foundation of EU 
Studies: Revisiting the Neofunctionalism of Ernst B. Haas." Journal of European Public Policy 12(2), 237-254.

Ross, Michael L. and Erik Voeten. 2015. "Oil and International Cooperation." International Studies Quarterly 60(1), 85-97.

Sohn, Hyodong. 2017. "EU Energy Policy Change and Energy Security: Agenda Entrepreneurship of the European Commission." Master's Thesis, Yonsei University.

Tingley, Dustin and Michael Tomz. 2014. "Conditional Cooperation and Climate Change.” Comparative Political Studies 47(3), 344-368.

Victor, David G. 2006. "Toward Effective International Cooperation on Climate Change: Numbers, Interests and Institutions." Global Environmental Politics 6(3), 90-103.

Victor, David G., Amy M. Jaffe and Mark H. Hayes. 2006. Natural Gas and Geopolitics: From 1970 to 2040. Cambridge: Cambridge University Press.

Wallace, Helen. 2010. "An Institutional Anatomy and Five Policy Modes." In Mark A. Pollack, Alasdair Young, and Helen Wallace eds., PolicyMaking in the European Union. New York: Oxford University Press, 69-104.

Whitten, Guy D. and Paul M. Kellstedt. 2013. The Fundamentals of Political Science Research. Cambridge: Cambridge University Press.

Young, Alasdair R. 2010. "The Single Market-Deregulation, Reregulation, and Integration." In Mark A. Pollack, Alasdair Young, and Helen Wallace eds., Policy-Making in the European Union. New York: Oxford University Press, 107-131. 
Institutions for European Energy Cooperation: Dyadic Data Analysis of Electricity Network Interconnections $\mid 447$

Appendix 1. Descriptive Statistics of the Variables

\begin{tabular}{|c|c|c|c|c|c|}
\hline Variables & $\mathbf{N}$ & Mean & Standard Deviation & Min & Max \\
\hline $\begin{array}{l}\text { Level of Electricity Network } \\
\text { Interconnection }\end{array}$ & 820 & 316.0341 & 1620.894 & 0 & 24939 \\
\hline Neighboring Country & 820 & .0817073 & .2740855 & 0 & 1 \\
\hline Electricity Consumption & 820 & 222.5768 & 244.1408 & 7.635 & 1419.878 \\
\hline $\begin{array}{l}\text { Current Electricity Energy } \\
\text { Cooperation Experience }\end{array}$ & 820 & .2182927 & .4133393 & 0 & 1 \\
\hline North Sea Region & 820 & .054878 & .2278811 & 0 & 1 \\
\hline Baltic Sea Region & 820 & .0439024 & .2050031 & 0 & 1 \\
\hline Continental Central South Region & 820 & .0439024 & .2050031 & 0 & 1 \\
\hline Continental South West Region & 820 & .0036585 & .0604119 & 0 & 1 \\
\hline Continental South East Region & 820 & .0256098 & .1580644 & 0 & 1 \\
\hline Continental Central East Region & 820 & .0670732 & .2503013 & 0 & 1 \\
\hline $\begin{array}{l}\text { Former Electricity Energy } \\
\text { Cooperation Experience }\end{array}$ & 820 & .3207317 & .4670427 & 0 & 1 \\
\hline ATSOI & 820 & .0012195 & .0349215 & 0 & 1 \\
\hline BALTSO & 820 & .0036585 & .0604119 & 0 & 1 \\
\hline ETSO & 820 & .3365854 & .4728301 & 0 & 1 \\
\hline NORDEL & 820 & .0073171 & .0852784 & 0 & 1 \\
\hline UCTE & 820 & .3085366 & .4621712 & 0 & 1 \\
\hline $\begin{array}{l}\text { Cooperation Experience in the } \\
\text { Region }\end{array}$ & 820 & .4280488 & .4950979 & 0 & 1 \\
\hline $\begin{array}{l}\text { Level of Cooperation Experience in } \\
\text { the Region }\end{array}$ & 820 & 36.14634 & 28.27314 & 0 & 112 \\
\hline
\end{tabular}


